ELORE (ISSN 1456-3010), vol. 19 - 2/2012.

Julkaisija: Suomen Kansantietouden Tutkijain Seura ry.

[http://www.elore.fi/arkisto/2_12/hytonen_koskinen-koivisto.pdf]

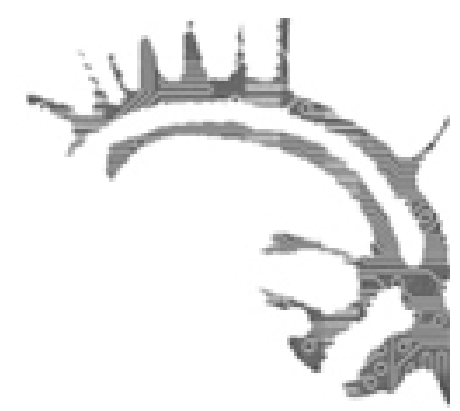

\title{
Ajankohtaista
}

\section{AMERIKKALAISET FOLKLORISTIIKAN ALKUJÄLJILLÄ}

\author{
Kirsi-Maria Hytönen ja Eerika Koskinen-Koivisto
}

\section{Timothy Lloyd (American Folklore Society) vierailulla Suomessa}

Ulkomaisilla folkloristivierailla on aina keino saada suomalainen isäntäväkensä hymyilemään hyväksyvästi: tarvitsee vain kertoa, miten jo ensimmäisellä viikolla omissa folkloristiikan opinnoissaan sai kuulla suomalaisesta folkloristiikasta ja suomalaisesta menetelmästä. Suomi näyttäytyy folkloristiikan maailmanlaajuisessa oppihistoriassa alkukehtona, johon nykyinen tieteenala perustuu. American Folklore Societyn (AFS) toiminnanjohtaja Dr. Timothy Lloyd vieraili elokuussa 2012 Suomessa vaimonsa Barbara Lloydin kanssa. Barbara Lloyd on folkloristi, joka työskenteli ennen eläköitymistään apulaisjohtajana Ohio State Universityn Center for Folklore Studies -keskuksessa. Kahden ja puolen viikon mittainen vierailu oli pitkään folkloristiikan parissa työskennelleen pariskunnan ensimmäinen ja tarjosi lyhyttä konferenssimatkaa paremman mahdollisuuden molemminpuoliseen tutustumiseen. Barbara ja Timothy Lloydin isäntänä toimi Jyväskylän yliopiston historian ja etnologian laitos. Lisäksi he vierailivat Suomalaisen Kirjallisuuden Seurassa ja Helsingin yliopiston folkloristiikan oppiaineessa. Timothy Lloydin vierailun ohjelmaan kuului luentoja sekä työpajoja. Vierailun yhteydessä järjestettiin myös folkloristiikan ja etnologian tulevaisuuden haasteita käsittelevä keskustelutilaisuus. Vierailun rahoittivat Fulbright Specialist -ohjelma ja Jyväskylän yliopiston historian ja etnologian laitos.

Jyväskylässä järjestetyssä työpajassa Timothy Lloyd kommentoi tutkijoiden ja tohtorikoulutettavien rahoitushakemuksia ja alusti hakemuksen tekemisen taiteesta. Sekä 
Jyväskylässä että Helsingissä Lloyd esitteli AFS:n toimintaa. Luennollaan American Folklore Studies (Yesterday and) Today Lloyd käsitteli oppiaineen historiaa ja kehitystä Yhdysvalloissa. AFS perustettiin vuonna 1888 museoissa työskentelevien antropologien ja kirjallisuudentutkijoiden yhteistyönä, ja alusta asti yhdistyksen näkyvin tuote on ollut tieteellinen julkaisu, Journal of American Folklore. Lloyd nosti luennollaan esiin eräiden yksittäisten henkilöiden panoksen organisaatioiden luomisessa. Hän piti erityisen tärkeänä 1930-luvulta alkanutta ja 1970-luvulla institutionalisoitunutta kehitystä, jossa folkloristiikkaan liittyvää tallennus- ja tutkimustyötä on esitelty suurelle yleisölle esimerkiksi populaarien julkaisujen, radio-ohjelmien sekä festivaalien muodossa. Amerikkalaiselle folkloristiikalle, samoin kuin AFS:n toiminnalle, on tyypillistä jakautuminen akateemiseen tutkimukseen ja niin sanottuun "public folkloreen", yliopiston ulkopuolella tehtävään tallennus- ja tutkimustyöhön. Jakautuminen ei tarkoita eripuraa, vaan hyvää yhteistyötä tehdään esimerkiksi AFS:n sisällä. Edellisessä seuran jäsenille osoitetussa kyselyssä kävi ilmi, että puolet AFS:n jäsenistä ilmoitti työskentelevänsä yliopistojen ulkopuolella.

Luentojen ja työpajan lisäksi Timothy Lloyd osallistui Jyväskylässä järjestettyyn keskustelutilaisuuteen etnologiatieteiden haasteista. Paikalla oli myös vierailevia tutkijoita eri puolilta maailmaa, esimerkiksi apulaisjohtaja Dr. Ruth Olson Center for the Study of Upper Midwestern Cultures (Wisconsin, USA) ja Dr. Yael Zilberman Ben Gurion yliopistosta (Israel, Beer Sheva). Tilaisuuden puheenjohtajana toimi professori Laura Stark, joka esitteli alkupuheenvuorossaan, mitä etnologia on ja mitä etnologit Jyväskylässä tutkivat. Keskustelussa etnologiatieteiden haasteiksi todettiin taistelu näkyvyydestä, oppituoleista ja rahoituksesta sekä rajankäynti ja päällekkäisyys lähitieteiden välillä. Toisaalta todettiin, että juuri nämä voivat kääntyä myös vahvuudeksi. Asemassa, jota pyritään jatkuvasti parantamaan eikä mitään ei voida ottaa itsestäänselvyytenä, on pakko pysyä aktiivisena ja dynaamisena. Vahvuutena nähtiin myös etnologiatieteiden substanssiosaaminen, ihmistä lähelle pyrkivät aineistonkeruumenetelmät sekä ammentaminen alojen tutkimusperinteen ytimestä.

Vierailun tarkoituksena oli tutustuttaa suomalaisia American Folklore Societyn toimintaan ja myös lähettää Lloydien mukana viestiä ajankohtaisesta suomalaisesta tutkimuksesta valtameren taakse. Lloyd toivoi näkevänsä mahdollisimman monta suomalaista tutkijaa seuransa vuotuisessa tapaamisessa. Hän myös muistutti, ettei seuran julkaisu nimestään huolimatta rajoitu vain amerikkalaisen folkloren tutkimukseen. Julkaisun päätoimittajina toimivat tällä hetkellä suomalaisillekin tutut folkloristit Tom DuBois ja James P. Leary.

Timothy Lloydin luento SKS:ssa videoitiin ja se on nähtävissä osoitteessa [http:// bambuser.com/v/2893002]. Lisätietoa American Folklore Societysta saa seuran verkkosivuilta www.afsnet.org.

Filosofian maisteri Kirsi-Maria Hytönen ja filosofian maisteri Eerika KoskinenKoivisto viimeistelevät etnologian väitöskirjojaan Jyväskylän yliopiston historian ja etnologian laitoksessa. 